\title{
Velkommen til flertallets verden - den religiøse
}

Ole Wever

\section{Vi bør diskutere konkrete spørgsmål, hvor religiø- se og andre synspunkter kan brydes, i stedet for at gøre disse diskussioner til for og imod religion i politik}

Før og efter 1989 - sådan troede vi, indtil for nyligt, at historien skulle fortælles. Murens fald og den kolde krigs afslutning var det store skift for os, der havde oplevet den kolde krig. I fremtidens historiebøger kommer det snarere til at hedde 'før og efter 1979', med den iranske revolution som vendepunktet. Den islamiske revolution var ikke det første eksempel på religionens genkomst i verdenspolitikken, men dels fik det konkrete tilfælde større blivende betydning end de andre (fordi det skete i en betydelig regional magt, og fordi regimet har holdt sig ved magten i nu over 30 år), dels igangsatte 1979 en generel eftertanke i øst, vest, nord og syd: Hvordan kunne et af regionens mest moderne og højtuddannede lande med en ældgammel civilisation lave sådan et sving? Det nye var, at vi ikke bare så 'efterslæb', men snarere en ny retning, historien kunne tage.

Hvad er undtagelsen, og hvad er reglen om mennesker?

Menneskeheden er altovervejende religiøs. Ateister udgør formodentlig få pct., og ikke-troende måske op til 15 (med ret stor måleusikkerhed pga kinesernes uafklarede retning). Af de mindst 85 pct. troende har det store flertal sandsynligvis troen som en ganske afgørende del af deres liv, med en helt anden intensitet end den normaldanske tro.

Omkring halvdelen af klodens befolkning mener, at troen rettelig bør have væsentlig indflydelse på indretningen af samfundet. Altså en vid udbredelse af netop det, de fleste i Europa mener, er den sikre vej til katastrofer: sammenblanding af religion og politik. Vi mærkede ikke så meget til det i lang tid, for folk blev 
globalt holdt nede og på plads af regimer, der svingede vores sekularistiske fane højt. Når 1979 udløste så megen bekymring langt ud over spørgsmålet om mulig islamistisk afsmitning, skyldtes det, at man i store dele af verden kunne iagttage en krise for den vestlige udviklingsmodel.

Forklaring: Med afkolonialiseringen blev nye stater verden rundt overtaget af vestligt uddannede eliter med et projekt om at skabe en stat efter vestligt forbillede. 1950'erne og 60'erne var domineret af varianter af 'moderniseringsteori', der diskuterede, hvordan man kunne få alle disse nye stater hen ad samme landevej, som vi andre havde tilbagelagt. Nogle lagde sig i den Sovjetinspirerede side af vejen, andre i den USA-inspirerede. Og eliterne havde af mange gode grunde travlt med at stække tidligere magtcentre såsom etniske og religiøse ledere. Væsentlige elementer i projektet blev derfor nationbuilding. Staten skulle være sekulær, og de religiøse ledere placeres i fortiden.

\section{Sekularisme under pres}

Efterhånden som projektet med at blive en vestlig stat blev mindre og mindre overbevisende, kom også den sekularistiske del af pakken under pres.

Spørgsmålet om, hvem der er reglen og hvem undtagelsen, blev stillet mest elegant af Peter Berger i 1996. Religionssociologen Berger havde tidligere været en af de ledende teoretikere inden for sekulariseringsteori, der netop forklarede, hvorfor alle samfund ville bevæge sig fra religiøse definitioner til sekulære samfund.

$\mathrm{Nu}$ skulle han anmelde et stort forskningsprojekt og bogværk, fem tykke bøger med resultaterne af et stort komparativt projekt under det amerikanske videnskabsakademi, 'fundamentalismeprojektet'. Med stor empirisk detaljerigdom og systematisk teoriudvikling undersøges her 'fundamentalisme' i alle de større religioner.

Men Berger studsede. Det blev alt sammen behandlet som om, det var 'mærkeligt', som om det var en afvigelse, der krævede forklaring. Men, indvendte han, denne form for insisteren på at lade de sande religiøse indsigter slå igennem på samfundsmæssig og politisk praksis, det var og er jo det normale - gennem historien og verden rundt i dag. Her sad snesevis af amerikanske universitetsprofessorer og skrev om det menneskeligt normale, som om det var et særligt fænomen, der skulle have en etikette og en diagnose. Det forklaringskrævende, afvigende fænomen var, konkluderede Peter Berger drilsk: den amerikanske universitetsprofessor. Disse distancerede iagttagere, der skilte religion fra det $\varnothing$ vrige liv og udviklede en helt særlig måde at omgås hinanden og andre.

Religiøs politik fremstår i de dominerende akademiske modeller 


\section{TEMA: RELIGION I INTERNATIONAL POLITIK}

som ikke bare 'forklaringskrævende' men også farligt! Det giver god mening i det store historiske og idéhistoriske billede. Det moderne samfund, hvor vores civilisation har taget form, er på mange måder skabt af to afgørende træk. Først et politisk og så et menneskeligt. Det politiske krystalliseres dels i Thomas Hobbes' Leviathan, dels i fredsslutningerne efter 30 års krigene.

Erkendelsen her var, at hvis vi vedblev med at lade tro være noget, der kunne begrunde krig, ville der aldrig blive fred. For tro er en tros sag, og derfor kan der aldrig gives sikre, endelige svar - og vi vil have uenigheder, der kan begrunde nye krige i en uendelighed. Eneste løsning var at sige, at religion fjernes fra den internationale politik og gøres først til et 'indenrigspolitisk' anliggende (herskeren bestemmer trone for sit folk) og siden et endnu mere indre anliggende, nemlig privat for den enkelte. Men under alle omstændigheder ikke noget mellem staterne, som man kunne føre krig om. I det lys er det et sikkerhedsproblem, så snart religion stikker hovedet frem i en politisk sammenhæng.

Den anden væsentlige grundsten, som mange ser truet, så snart religion melder sig i det politiske spil, er oplysningstidens opdyrkelse af det myndige menneske. Politisk autoritet kan kun komme fra mennesker. Historisk bevægede europæiske og amerikanske samfund sig fra renæssancen og især siden reforma- tionen, religionskrigene og oplysningstiden gradvist væk fra eksplicit og generelt anerkendt forankring af den politiske orden i religiøse strukturer - hen mod en politisk orden grundlæggende funderet i rent menneskelig historie, fornuft og vilje.

I princippet bør der intet være i vejen for, at deltagere i den politiske proces personlig henter deres begrundelser og moralske standarder fra religiøse kilder, hvorimod meget få i Vesten vil acceptere, at nogen instans - et Vogternes Råd - tildeles magt eller kompetencer i det politiske samfund som repræsentant for en religiøs sandhed.

\section{Principiel åbenhed}

Vel netop fordi vores samfund har udviklet sig via frigørelse fra institutionel magt hos kirken, er det let at reagere på enhver religiøst funderet politik, som om den var første trin på vej mod et teokrati. Det er stærkt omdiskuteret, men jeg mener, at det vil være principielt forsvarligt og politisk fordelagtigt at udvise principiel åbenhed over for, at religiøs motivation er lige så legitim som enhver anden i et moderne, demokratisk samfund, så længe der ikke bygges magtstrukturer med begrænsning af flertallets mulighed for fremtidigt at overtrumfe disse (eller med indskrækning af mindretalsbeskyttelse, $\mathrm{fx}$ religionsfrihed). Derfor var vi bedre tjent med at diskutere konkrete spørgsmål, hvor religiøse og 
andre synspunkter kunne brydes over sagerne selv, i stedet for hele tiden at gøre disse diskussioner til en diskussion for og imod religion i politik. Og især frem for at gøre diskussionerne til et spørgsmål om trusler.

Den aktuelle situation er, at de fleste diskussioner af verdenspolitikkens religiøse dimensioner udgår fra grundtonen: religion i politik er en trussel, og religion i sikkerhedspolitikken er en sikkerhedstrussel.

Det er egentlig underligt. Religion i den internationale politik har haft to næsten uafhængige afdelinger i biblioteket. Et sted finder vi litteraturen om religiøst motiverede konflikter og terror - en afdeling, som er vokset dramatisk de sidste 10 år. I et andet, mere støvet hjørne finder vi en mindst ligeså anerkendt og gennemtænkt litteratur om religion som grundlag for 'gode gerninger' i international politik.

Danskernes engagement i verdens problemer har i høj grad været anført af kirkelige organisationer, der var pionerer i udviklingsarbejdet. Moralsk lederskab i forhold til konfliktløsning og forsoning er meget tit udsprunget fra religiøse skikkelser. Den mest berømte og en af de mest vellykkede forsoningsprocesser, den i Sydafrika, var næppe lykkedes uden en religiøs dimension. I sin tankevækkende bog Det Helliges Ambivalens skriver R. Scott Appleby, at både fredsmagere og voldelige aktører ofte har hellige oplevelser som udgangspunkt. Religion er det men- neskelige svar på en erfaring, der opleves som hellig, skriver Appleby. Både voldelige ekstremister og fredsmagere er militante. Begge 'går til ekstremer'.

De fleste ved godt, at der er denne 'gode religiøse politik', men alligevel ræsonnerer de fleste ud fra den anden. Og derfor er der meget få, der protesterer, når det fremstilles som om at religiøs radikalisering pr. definition er første skridt i retning af voldelige eller terroristiske handlinger - hvor det principielt lige så godt kunne være første skridt for en ny Moder Teresa.

Et af de klare udtryk for at de fleste i Vesten var og er uforberedte på og uvillige til at anerkende den globale, religiøse normalitet, er at religion bortforklares som noget andet. Tre bortforklaringer er særligt udbredte. Først hører vi, at der reelt er tale om magtpolitik og manipulation - ledere anvender religiøse begrundelser. Slobodan Milosevic var kommunist først, så blev han nationalist, da tidsånden blæste den vej, og i dag ville han sikkert være blevet en stor religiøs leder. Der er meget rigtigt $i$, at ledere anvender den retorik, der giver bedst udbytte, men det flytter bare det gode spørgsmål ét felt, for hvorfor er det lige, at en given retorik virker - det må være fordi, der er genklang hos befolkningen for den slags begrundelser, og vi må derfor stadig interesse os for, hvad selve det religiøse grundlag er for politik i religioners navn. 


\section{Som andre identiteter}

Den anden type bortforklaring lægger vægt på, at religionens betydning i international politik kan forstås på lige fod med andre identiteter. Vi brugte akademisk en stor del af 1990'erne på at lære at forstå identitetspolitikkens rolle for sikkerhed og storpolitik - særligt foranlediget af udviklingerne i Eksjugoslavien og det tidligere Sovjetunionen. Mange forsøger at overføre disse tanker på dagens udfordringer; hvad der gjaldt for konflikter mellem kroater og serbere, må også gælde islamisk radikalisme eller det kristne højre i USA. Ja og nej. Det er rigtigt, at troende typisk finder sammen med fæller og kommer til at opfatte sig som et fællesskab, der kan være truet, og som gruppe vil et sådan religiøst funderet fællesskab have mange træk til fælles med nationale og etniske grupper.

Men det er så at sige kun andet skridt, ikke det første. En nation handler om fællesskabet, man handler på vegne af denne så at sige 'horisontale' gruppe, menneske-tilmenneske. Men den religiøse handling har ofte mest grundlæggende at gøre med det 'vertikale' forhold mellem den enkelte og det overjordiske element. Dette skal ikke formuleres for håndfast, for så bliver det for protestantisk-specifikt med et indre gudsforhold som det første og fællesskabet som noget sekundært. Det er klart, at aktiviteterne med andre - ritualer, praksis - har en langt mere central status i mange andre trosretninger, men det er stadig væsentligt at fastholde, at religion er 'folkelige fællesskaber plus'; det er en gruppe af mennesker men også noget mere. Religiøse mennesker handler ikke primært ud fra fællesskabets værdi i sig selv, men ud fra overvejelser om den væren, de tolker i religiøse termer og verdens indre mening. Og det gør ofte en forskel med hensyn til hvilke handlinger der giver mening.

Endelig er der en tredje udbredt forklaring, der reducerer religion til et spørgsmål om udvikling og økonomi. Dette er tæt forbundet med den klassiske sekulariseringstese, og vi ser det i nyere tid fx med opfattelsen, at den langsigtede løsning på problemer med terror fra mellemøstlige lande må være økonomisk udvikling.

Det kan der være meget om, men det ændrer ikke ved, at man for det første må være yderst skeptisk over for den klassiske forventning om, at religion forsvinder med modernisering, for den teori har altid været skræddersyet til Europa og haft et stort forklaringsproblem placeret vestpå henover det meste af Nordamerika. For det andet kan udviklingsstrategiske overvejelser om at undgå radikalisering ikke være anledning til at droppe forståelse og håndtering af mennesker i verden i dag.

Særligt når det gælder det spørgsmål, der motiverer dansk interesse 
for 'religion i verdenspolitikken', terror og islamisk fundamentalisme, er det vigtigt at medtænke både en socio-økonomisk dimension og en 'indholdsmæssig', der er både religiøs og politisk. Diskussioner om 'radikalisering' fanger ofte både det socio-økonomiske - under hvilke vilkår er især unge mennesker mest tilbøjelige til at søge i 'radikal' retning (hvor de samme faktorer imidlertid kan give rockerbander, politisk ekstremisme eller religiøs radikalisering) - og den religiøse del af kabalen (hvilke religiøse ideer er i cirkulation, og hvornår er det sandsynligt, at identitetssøgen fører i religiøs retning).

Men der mangler ofte den politisk-religiøse del. Det er relativt let at forklare, hvorfor fx unge indvandrere i Europa kan komme ud i en tilspidset udgave af ungdommens identitetskriser, hvor de føler sig afvist i det nye land og frakoblet det gamle miljø, og da søger efter identifikation, der tilbyder en forøget selvfølelse ved at blive en del af noget stort. Men hvorfor vælge de mest radikale og antivestlige udgaver af islam?

\section{Den sande islam}

Islamkritikere springer denne mellemregning over ved selv at omfavne islamisterne og erklære denne udgave den mest sande islam, men i virkeligheden er det alt andet end selvfølgeligt, at de skal vælge disse vari- anter. Det kan slet ej heller forklares som udtryk for 'traditionalisme' og 'middelalderlige miljøer' i vores samfund - tværtimod. Pointen omkring disse radikaliserede unge er jo meget ofte, at de netop ikke er 'traditionelle' i betydningen, at de har overtaget en éntydig dogmatik, der nærmest er 'nedarvet'.

De er inderligt moderne, da de har indset - nok smerteligt - at der er en mangfoldighed af mulige overbevisninger, og de har almindeligvis også frigjort sig fra de traditionelle religiøse autoriteter, der belærte forældrene, og er blevet frisat som andre unge i et moderne samfund. Her vælger de så frit i tidens religiøse supermarked, og det springende punkt er derfor, hvorfor radikale, voldelige og anti-vestlige varianter af islam så har en vis appel.

Det kan ikke bortforklares med gammeldags koldkrigsagtige 'hjernevask'-teorier, hvor hele ansvaret lægges på imamer. Nej, det bliver nødvendigt at medtænke en politisk forståelse. Det er den verdenssituation, vi har været med til at skabe, der gør netop disse Vesten-fjendske, krigeriske udgaver særligt attraktive. Radikalisering og terrorisme kan derfor ikke forstås, hvis man reducerer det til et socialpsykologisk fænomen. Man må anerkende religiøsitet som religiøsitet, og at enhver religion tolkes og udmøntes i en social sammenhæng. For disse unge muslimer spiller Vesten - ikke mindst det krigsførende - en meget stor rolle. 


\section{TEMA: RELIGION I INTERNATIONAL POLITIK}

En af konsekvenserne heraf er, at krigen mod terror må foregå på to planer. Vi kan næppe påvirke ledernes grundlæggende motiver og fjendtlighed med imødekommelse eller udspekuleret punktering af fjendebilleder. Den islamistiske hvervekampagne kan vi kun underminere, hvis vi forstår, hvordan konflikten ser ud fra deres side.

Her bliver det afgørende at skelne mellem to typer af konflikter, hvor religion er på spil. På den ene side religion-mod-religion og på den anden 'religiøs politik' kontra sekularisme. En af de største fejlkilder er, at automatreaktionen for de fleste, når ordene religion og konflikt sættes sammen, er at tænke 'religionskrig'. Men det er for det meste en skæv diagnose. I vor tid står de fleste religionsrelaterede konflikter mellem på den ene side en part, der ønsker at bringe religion mere kraftigt ind i politik, og på den anden side en, der ønsker at holde religion ude. Altså 'religiøs politik' mod 'sekularisme'. Det gælder i USA, islamiske lande, Indien og mange, mange andre steder.

\section{Fra Guinea til Kenya}

Nogle af de vigtigste eksempler i dag på den første type konflikter findes i et bredt bælte henover Afrika, hvor der ofte optræder deciderede konflikter mellem 'muslimer' og 'kristne' med gensidige angreb på kirker/moskéer med mere. Man kan også hævde, at Israel-Palæstinakonflikten i stigende grad har bevæget sig til en sådan konflikt. Den palæstinensiske side anføres mere og mere af islamistiske grupper, der ser Israels jødiske karakter som problemets kerne, og Israels hardlinere udgøres af ortodokse jødiske grupperinger. Så, jo, der er konflikter i verden, der følger modellen 'religionskrig' (også kaldet 'civilisationernes sammenstød'), men det er stadig vigtigt, at vi undgår tankeløst at overføre denne model på de anderledes situationer.

Ikke kun fordi langt de fleste religionsrelevante konflikter snarere følger religion-versus-sekularisme modellen (eller 'fundamentalisme' mod 'sekularisme'), men også fordi det gælder den globalt mest sprængfarlige konfliktakse, den mellem islamister og Vesten. Meningsmålinger peger alle på, at fjendebilledet af Vesten langt mere handler om, at vi er dekadente, umoralske materialister, der har tabt vores egen åndelige tråd og nu dyrker et indholdstomt projekt, hvor verden - og islam - ifølge de fleste muslimer ville være bedre tjent med, at vi genfandt en åndelig kerne i Vesten. Dette er helt forskelligt fra de 'rigtige' religionskrige i Middelalderen, hvor kernen var kampen om den rette lære og krig mod fejlagtige forståelser. I dag er den stærkeste religionspolitiske magt den sekulære position, der har været internationalt enerådende indtil for få årtier siden. 


\section{Tilfældet USA}

En særlig udfordring for at forstå det internationale landskab af religioner og sekularismer er den amerikanske case. USA er i bund og grund et stærkt religiøst samfund, og det kan derfor være svært at forstå doktrinen for adskillelse af religion og politik, princippet om nonestablishment i forfatningen. Den amerikanske selvfremstilling er ofte, at USA skabtes af pilgrimme, der søgte et sted med religionsfrihed.

Men de søgte et sted at indrette samfundet efter deres egen religion. De fleste ønskede statsligt sanktioneret religion. En af Virginias første love udmålte bøden (i pund tobak) for at udeblive fra søndagsgudstjeneste. USA's velsignelse var, at med de mange protestantiske sekter var alle mindretal. Derfor var det først ved føderationsdannelsen, at forbuddet mod statskirker fandt generelt gehør. Sat på spidsen handler den amerikanske form for sekularisme hverken om at forsvare staten mod kirken eller kirken mod staten; den er først og fremmest et forsvar af troende mod andre trosretninger.

Der er imidlertid en meget opbyggelig lære i den amerikanske case. I dagens globaliserede verden er vi alle et mindretal. Mon ikke man begynder at lære det samme som pilgrimmene i USA, der måtte give hinanden udstrakt religiøs tolerance - for at sikre egen religionsfrihed? Ellers er det mest bemærkelses- værdige ved USA i netop disse år, at efter at årtier har været præget af 'kulturkrigene' mellem det religiøse højre og det sekulære venstre - ser vi nu træk, der minder om Europa med anti-islamisme, protester mod et islamisk kulturcenter nær Ground Zero i New York og trusler om afbrænding af Koranen. USA importerer kampagnematerialer og slogans fra Danmark og omegn. Inden vi lidt for hurtigt konkluderer, at USA og Europa nu er blevet ens, må vi minde om, at det ikke skete i 2001.

Efter terrorangrebene 11. september slog islamfjendtligheden langt stærkere ud i Europa end i USA. Vel først og fremmest fordi de to sprængfarlige emner indvandring og religion gik i hak i Europa, ikke i USA. I Europa er det største indvandrerspørgsmål og det største religiøse konfliktemne fokuseret på samme gruppe, muslimer. I USA har de religiøse stridigheder stået mellem det religiøse højre og en sekulær, mere eller mindre venstreorienteret kulturelite.

Men indvandring handlede om 'latinoer' og kørte helt for sig. Når vi nu ser islam-fjendtlighed skylle frem i USA, hvad handler det så om? Nok ikke særligt meget om islam, men snarere om Obama, om Kina, om økonomisk krise, om en generel utryghed i USA, der leder til protest imod alt fremmed, anført af Tea Party-bevægelsen og med en særlig forbitret intensitet, fordi så mange hvide, når alt kom til alt ikke 
kunne kapere en (relativt) sort præsident.

Den politiske polarisering i USA er 'drejet' nogle grader, og det har pludselig gjort en fremmed religion til skydeskive på en måde, der ikke passede med den tidligere polarisering. Kampene i USA er præget af, at samfundet er så religiøst, at selv stridigheder mellem forskellige varianter af en mere eller mindre sekulær statsforståelse har religiøsitet som bagtæppe.

\section{Europas sekularisme}

I Europa er omdrejningspunktet en langt mere og accelereret ambitiøs sekularisme. Især EU-Europa har bevæget sig i retning af at gøre sekularisme til en del af sin identitet. I det store globale billede er Europa klart det mest sekulariserede kontinent færrest er troende, og blandt de troende er der en langt færre, der mener, at deres tro har afgørende betydning for deres holdning til allehånde spørgsmål.

Ud over at være sekulariseret er Europa også sekularistisk, når princippet om adskillelse af religion og politik håndhæves nidkært og til tider selvretfærdigt. I den vedvarende søgen efter principper, der kan holdes op som 'europæiske værdier', fandt sekularisme vej til listen sammen med velfærdsstaten og den internationale retsorden med særlig stor overbevisning i de første år af det nye årtusinde, hvor Europa be- lejligt kunne defineres op imod både Osama bin Laden og George W. Bush.

Det blev Europas lod at forsvare sekularismen internationalt. At adskille religion og politik gik fra at være en præference til et princip og i stigende grad identitet. Ud over at gøre mange hverdagsproblemer sværere at løse, fordi parterne ser 'principper' på spil, hver gang et lokalt badeforhæng skal vurderes, er det også en risiko, at Europa får sværere ved at manøvrere i en post-vestlig verden med mange magtcentre uden for den traditionelle kreds, når disse ofte religiøst inspirerede magter møder et Europa, der ser sekularismen som et sandt og nødvendigt princip, et civilisatorisk fremskridt, de andre bør tilpasse sig.

Hvor Europa ellers på flere og flere områder er ved at lære at blive det lille kontinent i en stor verden og på nogle punkter måske bedre end USA kan vænne sig til at magten er blevet spredt og diffus - bliver den nye mulighed for at blive en diplomatisk spiller med over-proportional indflydelse måske på længere sigt hæmmet allermest af, at vi er religiøst ude af trit med det globale flertal.

Ellers vil religion for EU-Europa nok stå højt på dagsordenen i mange år fremover, både i nationale kontroverser omkring indvandrere og på europæisk plan især i domme ved menneskerettighedsdomstolen, hvor en kompleks afklaringsproces 
er ved at tage form i en trekant mellem religiøse flertal, mindretal og stater. De nationale traditioner og religionsretslige arrangementer varierer, og det gør også statens politiske forhold til dens flertalsreligion. I kombination med forskellen i karakter af de mange forskellige spørgsmål, der kan bringes for domstolen - oftere af ateister end af indvandrere, til tider af flertalsreligionen - giver det domme, der skaber mange præcedensovervejelser, men ikke en stabil, fælles forståelse foreløbig.

Realiteten er imidlertid, at de kirkeretslige og religionspolitiske arrangementer er blevet udsat for et ydre blik, som nok kan anfægte en del kreative arrangementer, hvor man nationalt har kunnet overbevise sig selv om det rimelige i 'ikke-religiøs morgenbøn'. Det danske arrangement vil næppe stå uændret om 10 år, og det bliver næppe en rent national proces, men vil være påvirket af en europæisk politisk og juridisk diskussion om religionens plads i det moderne europæiske samfund.

Mange andre steder rumler religiøse spørgsmål på forskellig vis. Kort kan fx nævnes Kina, hvor styret tydeligvis har en massiv frygt for, om det eksistentielle vakuum efter kommunismens idemæssige fald vil betyde et religiøst boom? Både 'hjemlige' og 'fremmede' religioner følges meget tæt af styret.

Et andet stort område i verden, der er usædvanligt uafklaret, er den arabiske verden efter revolutionerne, hvor spillereglerne har ændret sig dramatisk de seneste måneder.

\section{Mere islam, mindre terror?}

Det kan ende med en arabisk verden, hvor styrerne lægger mere afstand til Vesten, mens samfundene kommer til at rumme både flere, der kulturelt tilnærmer sig Vesten, og stærkere islamistiske bevægelser. Man kan meget vel forestille sig, at der bliver stærkere gennemslag for islamisme i de arabiske lande og mindre islamistisk terror.

Lidt firkantet sagt er disse bevægelser primært optaget af deres egne samfund, og de fik kun os i skudlinjen, fordi de vurderede, at forandringer hjemme hos dem selv var umulige. Hvis man tror, der er tale om en krig mellem to religioner, vil enhver styrkelse af islamismen i Mellemøsten være en styrkelse af 'vores fjende', men hvis man omvendt mener, at de mobiliserer i en krig for mere plads til religion, er det yderst muligt, at større udfoldelse hjemme og mere afstand til vestlige magtstrukturer vil flytte fokus væk fra Vesten som angrebsmål.

Mere islamisme og mindre terror (og mindre vestlig afhængighed af Mellemøstens olie) kan være nok så fordelagtigt for Vesten på længere sigt, men hvad det kommer til at betyde for mennesker konkret i de arabiske lande vil afhænge af mange kampe i deres fremtidigt formodent- 


\section{TEMA: RELIGION I INTERNATIONAL POLITIK}

ligt mere pluralistiske samfund. Der er jo ingen tvivl om, at de mest traditionalistiske religiøse aktørers politiske indflydelse ofte vil støde sammen med forventninger hos især bevægelser blandt ungdommen og kvinderne. Hvis den arabiske verden virkelig er ved at blive løsnet af årtiers forkrampede strukturer, vil vi formodentlig se nye former for kampe både inden for den religiøse arena om konkurrerende tolkninger og nyudviklinger og på det politiske felt om, hvor grænserne skal trækkes for stat, privat, religiøst, juridisk og andre sfærer i samfundet.

Disse korte eksempler fra forskellige verdensdele følger ikke simple, faste linjer eller modeller - og det gælder endnu mindre de langt mere detaljerede og dybsindige diskussioner i dette nummers egentlige artikler. Derfor peger de fremad i retning af, at den vigtige diskussion ikke hedder for/imod religion i politik. Især i en verden efter Vestens kontrol er politik selvfølgelig religiøs; spørgsmålet er ikke om men hvordan.

Lidt provokerende kan man måske hævde, at 'religion' er den gamle dagsorden - 0'ernes. Og det vi er i gang med i 10 'ernes årti er - skriver jeg i forlængelse af min artikel herom i forrige nummer af udenrigs - at lære at leve i en post-vestlig ver- den, hvor religion er en del af variationen. Der er ikke længere ét autoritativt center, der opstiller principper, værdier og målestokke - Vesten - og andre dele af verden, der skal måles herudfra.

Nej, der er nu magt bag mange forskellige tolkninger af historien, ansvar, fremtiden og rettigheder, og når disse forskellige tilgange i fremtiden kommer til at brydes mere ligeværdigt, vil det indgå heri, at der også er tale om både forskellige religioner, forskellige opfattelser af hvad religion er, og stor variation i hvilken rolle religion spiller politisk. Så religion indgår som en af mange dimensioner i vores mere mangfoldige verden. Og det er ikke en vestlig option at lege overdommer, der fortæller, at det er forkert. I bedste fald kan vi lære at leve i dén brogede verden med vores egne særheder mht. religionens rolle eller mangel på samme i samfundslivet.

Kampene handler derfor ikke om religion som sådan, ikke for/imod religion, ikke om religion som trussel mod en religionsfri politisk orden, for den vestlige illusion er faldet. Det gjorde den nok allerede i 1979 .

Ole Waver er professor i international politik ved Institut for Statskundskab, Københavns Universitet. 